\title{
Shame, de-subjectivation and passivity - on the metaphysics of the Self in Levinas and Agamben
}

\author{
Vergonha, des-subjetivização e passividade - \\ a metafísica do Eu em Levinas e Agamben
}

\author{
Fabricio Pontin ${ }^{1}$ \\ Branca Doria non morì unquanche, \\ e mangia e bee e dorme e veste panni \\ in anima in Cocito già si bagna, \\ e in corpo par vivo ancor di sopra ${ }^{2}$.
}

\begin{abstract}
This article provides a relation between the problem of shame in both Levinas and Agamben, focusing, for the most part, in the development of Levinas' metaphysics and its relation to the emotional tonality of shame in three works: "On Escape", "Time and the Other" and "Otherwise than Being". In stressing the unique take that Levinas has on metaphysics, I try to point at the tension between Jewish and Greek thought in Levinas, and his option for a radical notion of a situated understanding of the "ethical". Hence my interest in contrasting Levinas and Agamben, as Agamben's appropriation of Levinas' lexicon in his "Remnants of Aushwitz" places the subject in a political, and material, position which is ultimately uncompatible with Levinas' situational and metaphysical take on the self.
\end{abstract}

Keywords: Shame; Desire; Ethics; Affective Tonalities

Resumo: Este artigo fornece uma relação entre o problema da vergonha tanto em Levinas como em Agamben, focando principalmente, no desenvolvimento da metafísica de Levinas e sua relação com a tonalidade emocional da vergonha em três trabalhos: "De l'évasion", "Le Temps et l'Autre, "e" Autrement qu'être ou Au-delà de l'essence". Ao enfatizar perspectiva única que Levinas tem da metafísica, aponto tensão entre o pensamento judeu e grego em Levinas e sua opção por uma noção radical de uma compreensão situada do "ético". Daí o meu interesse em contrastar Levinas e Agamben, particularmente como a apropriação de Agamben do léxico de Levinas em seu "O que restou de Aushwitz" coloca o assunto em uma posição política e material, que, em última análise, é incompatível com a tomada de posição e metafísica de Levinas.

Palavras chave: Vergonha; Desejo; Ética; Tonalidades Afetivas;

${ }^{1}$ PUCRS/PNPD-CAPES < fpontin@gmail.com>..

${ }^{2}$ Dante Aleghieri, La Divina Commedia. INFERNO, Canto XXXIII, v. 141; 156 [Branca Doria is not dead, for he eats drinks and wear clothes]...[his soul already bathes in Cocino while his body pretends life on Earth] 
This article seeks to understand, for the most part, in the development of Levinas' metaphysics and its relation to the emotional tonality of shame in three works: "On Escape", "Time and the Other" and "Otherwise than Being". In stressing the unique take that Levinas has on metaphysics, I try to point at the tension between Jewish and Greek thought in Levinas, and his option for a radical notion of a situated understanding of the "ethical". Hence my interest in contrasting Levinas and Agamben, as Agamben's appropriation of Levinas' lexicon in his "Remnants of Aushwitz" places the subject in a political, and material, position which is ultimately uncompatible with Levinas' situational and metaphysical take on the self.

Shame is, in the last analysis, an existence that seeks excuses ${ }^{3}$

It could have been any large city in the world, but it was in Chicago. A woman was standing next to the Tribune building holding a cardboard. On the cardboard it was written "I am just hungry". On the floor, a coffee cup with some pennies, perhaps some dollar bills. Most people were passing around her, some would drop some coins without looking at her, some would keep minding their own business and ignore her presence. It was, in a way, as if she were invisible. To be fair, her image didn't fit the landscape: the magnificent and pale buildings, people in suits passing around, the expensive cars, nothing could possibly agree with the image of a hungry woman holding a cardboard.

Modern metropolises were overall successful in dislocating the image of the poor. Specially in the developed world, downtowns have been "cleared" of signs of poverty. There has been an urban dislocation of social differences: the projects, the favelas and even the refugee camps are expressions of this tendency. Poverty is dislocated to the margins of the city, so when it appears downtown it operates in the mode of a disruption. As I gaze at that woman next to the Tribune building, I am also immediately pushed to look at another direction. I evade her gaze and try to ignore the encounter with her, but as I do so, as I ignore her and

${ }^{3}$ Levinas, On escape [henceforth OE], p. 65 
continue walking towards my diner, is it not the case that I am exposed as affected? Doesn't the necessity to turn the gaze away, to avoid beingaffected, explicit the impossibility of not-being-affected?

Levinas begins the text On escape by articulating the question of the I and the non-I. The matters of subjectivity emerge in terms of satisfaction and need - later, Levinas will describe that in terms of a mastery of the self where one emerges capable of saying "I am". In On escape, Levinas is already attempting to articulate the bare existent as outside of the existing. This means that when an existent contracts existence, one emerges in a living present wherein one can master one's own relations to one-self and one's time ${ }^{4}$. The existent who is, is always already a modification of a form of existence. An existence that seeks to enjoy itself, without excuses, without disruption. In Time and the Other, Levinas will describe this form of enjoyment in the terms of the building of a mastery of the I - this means that the subjectivity which emerges from within existence as existing is now capable of taking control of the objects that surround it, integrating the existing world into its own existing present ${ }^{5}$. In this, a self acquires a density as it masters its form of existence. The materiality is the kind of density that builds up the identity of the self.

On Escape does not describe this in terms of materiality (the issue of materiality is introduced in Time and the Other, and fully developed in Totality and Infinite, as we will see), but it does describe the structured of intimacy where any enjoyment - even of objects - is already haunted by the impossibility of complete fulfillment. Desire is never fully fulfilled: the self always demands more. There is a constant lack in our being, there is always a need for something other than oneself.

Levinas is suggesting that the desire and intention of the $I$ is the beginning - it is important, it is even grounding, but it is not enough, in its disclosure, to describe the mode of givenness of the other - the revelation of the other in the encounter. But the lacking in our being that is characterized by an urge for the Other is, in On escape, thought in terms that are different, though not in conflict with the developments in further works like Time and the Other and Totality and Infinity. Presently, Levinas suggests that the urge for the Other is suppressed, in the self, by a mastery

\footnotetext{
4 Levinas, Time and the other [henceforth TO]: 52

5 TO:54 "[T]he existent is master of existing."
} 
of pleasure that seeks to take the place of the encounter, it seeks to affect pleasure rather than being-affected by a trauma ${ }^{6}$.

Allow me to suggest that at this point we have a tension between active affection and passive reception: a hedonistic attitude of seeking one's pleasure, in Levinas, is a striving to escape the presence of the other. Through hedonism the self seeks to get out of its own boredom, of its own similitude, and break into difference. However, Levinas is quick to point, this is a deceptive breaking out of being.

Pleasure, as materiality, is an attempt to evade being, to fulfill the demands of need, that exposes the pathological condition of ourselves: where being should have been triumphant it is now exposed as unable to accomplish its own necessities, and this exposition of the self as fragile is described by Levinas as shame. Shame is the incapacity of being to break with itself?

It is interesting to note how Levinas describes this incapacity: as the self is exposed in its bareness ${ }^{8}$, the $I$ tries to compensate for its shame with an attitude of "covering up". The gaze of the other exposes our own bare life, the gaze of the woman on the street in Chicago constitutes my need to find an excuse not to respond - paradoxically, this immersion in the self (i.e.: walking faster towards the restaurant) only exposes my own bareness beyond that Other.

Bareness, in this situation, has nothing to do with the clothes we are wearing. The men on Prada suits passing through the woman with an old jacket are not less "bare" because of their expensive clothes. Clothing might seek to find an excuse not to feel ashamed, not to be exposed, but as we attempted to cover up, there is a disruption in our own being that exposes our bareness - shame then unveils the self as visible to others. I evade the gaze of the woman precisely to avoid this disruption, but Levinas points that the disruption, the emergence of the pathological, is impossible to be escaped ${ }^{9}$.

What I am calling the pathological status of the $I$, our bareness, in Levinas appears in the relation of malaise and intimacy. I have already

\footnotetext{
${ }^{6}$ OE: $62-63$

7 OE: 65

8 I am translating "nuditè" as "bareness" rather than "nakedness".

9 OE: $64-65$
} 
described the structure of the need in being for an intimate relation with something external to itself, I have also described how this need is supplemented with a sense of pleasure, a hedonistic return to oneself in order to avoid exposition. Finally, we have seen that the attempt to escape the need for an outside exposes our own fragility, our own pathos. This pathological situation is always already related to the need for intimacy, but Levinas does not understand intimacy as a relation with others, it is rather a relation to oneself. Intimacy is the attempt to master the entirety of my being in the terms of my own being. The failure of this intimacy to oneself exposes the pathological: all I have described so far as the attempts to cover up our broken subjectivities are, in Levinas, described under the rubric of intimacy. My intimacy is exposed to others: as the woman in Chicago directs her gaze at me, my own broken self appears, I am suddenly bare and our tendency is to attempt to return to the undisturbed enjoyment of intimacy, but it is too late: my pure being has been exposed, and I can finally sense the presence of my self to myself.

Our own subjectivity is experienced in the form of this malaise, of a constant lacking. In Totality and Infinity these issues are further taken in consideration within the very unique interpretation Levinas has of metaphysics ${ }^{10}$. It is interesting to note in the use of the concept by Levinas is that he seems to refer to the metaphysics of presence in Heidegger. However, the usage of the term is re-appropriated in Levinas positively, which is in line with Levinas' insistence in reading the Greek philosophy tradition with Jewish lenses: Metaphysics is dislocated from within the self and moved towards the other - in the form of a desire towards something other than Being. Metaphysics is this form of conation.

For Levinas, the platonic notion of goodness beyond being, and the Cartesian good infinite is the ground for such form of Greek metaphysics: desire, metaphysical desire, acquires in this context a direction towards the other: at first there is a need that calls the Other into being, and in there is a desire from the side of the other that obligates my response towards him. The encounter brings this metaphysical desire even from my part - into play. 
Now we see how metaphysical desire opens up a practice, in a relation with the other in the mode of a face-to-face ${ }^{11}$. This rupture of totality means that the transcendence of the other breaks down selfhood. The other is put in an asymmetrical and absolute relation with the metaphysical desire - it divides the sea of metaphysics as a totally other desire $^{12}$.

The structure of the other is such, it is so dense, so alien, that it cannot be grasped by myself. But in language, particularly in dialogue, I have a relation to the other. And yet, in such linguistic relations, alterity is given from the position of the same: this means that the self remains as it is affected by the other. But it does not remain as it were, it remains as affected by this other that emerges and questions the solitary life of the self. Hence, the foundational structure of the self is limited by the emergence of the other - the field of solitary existence is limited by the materiality of the other. In this sense, if Ethics emerge from within the encounter with the other, and the other appears metaphysically, we have to situate Ethics within the realms of metaphysical desire, as a mode of presentation which is other than a disclosure, this mode of presentation is called a Face and marks Levinas inquiry into a more abstract discussion as to the mode of constitution of morality and the relation between the context of signification wherein you apprehend objects and the reality of the other- which is ahistorical and anarchic ${ }^{13}$, or, as Steinbock puts it, it is given in the mode of not-being-able-to-be-given ${ }^{14}$.

On Escape does not offer us such developed metaphysical consideration of the placement of the self and the Other, but it suggests an interesting insight into the structure of subjectivity as it appears to itself. Consciousness of oneself always emerges presently, one is immediately exposed to oneself in one's bareness, existence comes into consciousness as a shock, the shock of the incomprehensibility of the plenitude of being. The history of western philosophy, for Levinas, is the history of this shock $^{15}$.

\footnotetext{
${ }^{11}$ idem

${ }^{12}$ TI:39

${ }^{13}$ TI: 52
}

${ }^{14}$ Steinbock, Anthony. "Generativity and the scope of generative phenomenology" in WELTON, Donn. (Org) The New Husserl: A critical reader. Bloomington: Indiana University Press, 2003 (p. 307)

15 "And yet the value of European civilization consists incontestably in the aspirations of idealism, if 
196 | Veritas | Porto Alegre, v. 63, n. 1, jan-mar. 2018, p. 190-205

It seems that towards the end of On Escape Levinas starts to develop what will be described as "Totality" in his future works. Ontology, the attempt to reduce the structure and experience of knowledge to beingitself is identified in Escape as the most acute attempt to surpass the limitations of being, surpassing the breaking-down of being by overstating being itself was the ultimate exercise on intimacy in western philosophy. In Levinas, this exercise of attempting to surpass Being is not in-itself totalitarian, but it might become so as the event that breaks down being is denied or attempted to be mastered in thought. This event, that Levinas points at the very last paragraph of On escape seems to be the event of the encounter and the responsibility to oneself that is brought up by the shame of one's intimacy, that is, the realizing of one's bareness as this other, this person that has a personal name, posits a scandal to my isolated subjectivity. In this sense, even truth, which was the matter of materiality and intimacy will be bound up with the social relation, in the mode of Justice. For Levinas, justice consists in recognizing in the Other my master. Truth comes from the Other, and not from thought, enlightenment or negativity, it emerges from discursive practices of intersubjectivity that are affected by the other from within the perspective of the home. In a way, this language, this Ethical language, takes the givenness of the other in consideration, it takes the historicity of the other as an event, not only as a data, but in its carnality. It is affected traumatically.

The sense of trauma, or astonishment, presupposes that my experiences anticipate other experiences. This posits a familiarity of experience, of relations - a home. This repeated experience protents something onto the future: you create a sense of safety where experience posits a number of structures that are ever-again fulfilled without interruption. Except that the encounter interrupts this familiarity even if you anticipate it. You can never situate an encounter in a familiar way. An encounter evades the intimacy where familiar structures are given and posits the $I$ as broken.

These dynamics will posit the structure of subjectivity, for Levinas, in terms of Being-a-Subject and Being-Subject, that is: Being a sovereign subject is always presupposing the encounter which strikes the intimacy, where the self is sovereign, with an external event. Agamben sees in this 
duality of the self an emergence of the fundamental structure of life as bare-life, and shame as the experience that opens this double movement.

II

To be ashamed means to be consigned to something that cannot be assumed. But what cannot be assumed is not is not something external. Rather, it originates in our own intimacy; it is what is most intimate in us (for example, our own physiological life). Here the "I"is thus overcome by its own passivity, its ownmost sensibility; yet, this expropriation and desubjectification is also an extreme and irreducible presence of the "I" to itself. It is as if our consciousness collapsed and seeking to flee in all directions were simultaneously summoned by an irrefutable order to be present at its own defacement, at the expropriation of what is most its own. In shame, the subject thus has no other content than its own desubjectification; it becomes witness to its own disorder, its own oblivion as a subject. This double movement, which is both subjectification and desubjectification is shame. ${ }^{16}$

Remnants of Auschwitz is not the first place where Agamben speaks of shame. Interestingly, the topic appears in an essay, "In this exile" ${ }^{17}$, which deals with the question of the terror squads in Italy. Agamben starts with the question of the experience of traumatic events and the emergence of political life and biological life in the same space. Here, he anticipates the interpretation that will be forwarded in Remnants of Auschwitz, that is: the camp and the situation of the subject in the camp exposes the bare structure of the $I$ as one's biological body becomes the place where politics occur $^{18}$. Obviously, Agamben is relying on the Foucauldian definition of biopolitics, the so-called "government of bodies", as the leading clue for his analysis. For Agamben, what biopolitics exposes is the impossibility of speaking of a "private" body or a "private space" of subjectivity. Intimacy is invaded by a politics of bios, a politics of the most bare and interior aspect of subjectivity ${ }^{19}$. There is something intolerable about this aspect of politics, but this experience of disgust beyond the intolerable is

\footnotetext{
${ }^{16}$ Giorgio Agambem, Remnants of Auschwitz [henceforth RA], p. 105-106

${ }^{17}$ Giorgio Agambem, In this exile (Italian Diary, 1992-94) in Means without end., [henceforth IE] p. 120-142

${ }^{18}$ IE:122

${ }^{19}$ idem
} 
paradoxical, because you speak of it while you are at the same time beingimmersed in this situation ${ }^{20}$. I find the idea of a hungry woman begging on the streets in Chicago to be intolerable, but at the same time I put up with it - and in a way I don't have an option except to put up with her presence.

In a sense, when Agamben writes Remnants of Auschwitz these considerations regarding the government of bodies are presupposed. When he reads Levinas and the question of shame within the context of the concentration camps he is, in fact, situating the discussion on shame as a political situation.

But political here is not a modality of thought, but a modality of space. In Agamben, politics are considered the field where subjectivity is immersed in its bareness. After a number of essays pointing at the concept of bare life from the late eighties until the early nineties, Agamben started with the development of his main work on what I will call a political ontology. This work becomes the Homo Sacer series, where Agamben seeks to provide a history of the sovereign subject and the impossibilities of the sovereign subject.

The question of the placement of the subject is immediately politicized by Agamben, the body of the subject becomes the place where politics occur, and the situation of this body is immersed in a point of indistinction between private and political life. The political subject that was inserted in a polis is now exposed in a camp. For Agamben the reality of this point of indistinction is found in its utmost bareness in the concentration camps

From these fields there is no possibility of returning to any classical conception of political philosophy ${ }^{21}$, any illusions that made the modern separation of a private and a public space possible are left aside when the process of desubjectification arises ${ }^{22}$. Our own physiological life becomes the object of a political experiment.

In Remnants of Auschwitz, Agamben focuses on the way these political experiments of oblivion, where the subject is exposed to its own disorder, allow us to speak of shame, the trace of this disorder, as the most

\footnotetext{
${ }^{20}$ IE: $124-5$

${ }^{21}$ IE: $138-9$

${ }^{22}$ RA:107
} 
proper emotive tonality ${ }^{23}$ of subjectivity. The Italian philosopher takes Levinas as the main reference for his development of shame at this point. If in his earlier work he was mostly concerned with Foucault and Gramsci, now the dynamics where identity arises are set differently. This is because Levinas points at the limitations of being-in-language as a matter of intimacy alone. The $I$ who speaks is always subject to the limitations of language. The event of language is precarious, and being, as being-inlanguage, finds in its intimacy this limitation. Becoming a subject is to become conscious of this discourse while at the same time being exposed at the trauma of the limitation of language.

It is still somewhat counter-intuitive to think of the description that Levinas provides of shame in a political sense, as Agamben seems to suggest. Again, I must stress that the philosopher wants to focus on politics as the placement of a determined form of being. In a way, Agamben accepts the anarchical placement of the subject in Levinas, but unlike Levinas he doesn't seem to resist the idea of politics and of doing politics as exercising proper subjectivity. Rather, he suggests that being-inlanguage, in its process of identity - which is a process of desubjectification - is in an anarchical position which is, at the same time, political, whereas the anarchical position of the Self-Other relation in Levinas is always metaphysical (in the peculiar sense the concept has for Levinas, of course).

My example with the woman in downtown Chicago indicates this ambivalence, it seems, in a broader sense: she is still peripheral even though she is in the geographic downtown of the city. Her presence is Alien to those surroundings, and those who are at home in the city attempt to integrate the disruption of her presence into the familiar landscape. There is an attempt to evade the encounter with the other. But Agamben is quick to point that this is not just about our encounter with that other person, it is also about the revelation of our own self as broken, as bare. Our language attempts to give testimony to the emergence of this strange, but because language still reproduces intimacy, it seems it is not enough. The affected subject can never completely make sense of its own passivity. The proximity of the other is never identical to the self, and the history of my being becomes the history of this conflict between trying to be a sovereign subject and being-subject. Up to this point, Agamben's reading 
is almost in line with Levinas, I must stress - but the political interpretation of the encounter, in Agamben, will be a breaking point with what Levinas has in mind.

For Agamben, this is a matter of political ambivalences: our demographic dislocation of the "undesirable" expresses an attempt at "domesticating" this process of desubjectification. Even as violence and poverty have decreased - and they have decreased a lot in the last hundred years - we seem to have dislocated the placement of the poor in our cities. We seem to have created small pockets of poverty (or, in the developing world, "pockets of development") that are dislocated to the margins of the city, in an attempt to separate - once again - the Camp from the City. This is a classical view in political philosophy, even in Aristotle: the political relevant life lives in the city - slaves and foreigners live in the fields outside. Locke justified slavery in terms of being outside the scope of protection of the law. The recent prosecution of Dreamers in the Trump administration, stresses the ambiguity of legal protection and the fragility of the right of have rights.

These ambivalences seem to be the political phenomena Agamben is trying to point at when he takes the issue of shame and desubjectification. The situation of our own political bodies is ambivalent, and even if we aren't ourselves victims of a determined failed policy or social experiment (as those who live in favelas and the projects are), we are exposed to the intolerable situation of these events. The limit situation of the Concentration Camps, in Agamben, explicits the bare life which is potential in all of us - the naked and hungry bodies of the survivors, when they face the liberator of the camps, expose a mutual shame. An impossibility to master one's own broken subjectivity ${ }^{24}$. Agamben never provides us with a way out of this situation where the subject is exposed as bare, he is quick to provide a grim description of the political situation and point at the need for an anarchic return to a notion of eudaimonia. Levinas, on the other hand, seems to deal with the structure of responsibility by appealing to the notion of ethical language. 


\section{III}

Ethical language, which phenomenology resorts to in order to mark its own interruption, does not come from an ethical intervention laid out over descriptions. It is the very meaning of approach, which contrasts with knowing. No language other than ethics could be equal to the paradox which phenomenological description enters when, starting with the disclosure, the appearing of a neighbor, it reads it in its trace, which orders the face according to a diachrony which cannot be synchronized in representation. A description that at the beginning knows only being and beyond being turns into ethical language. The enigma in which transcendence comes to flush has to be distinguished from arbitrariness and illusions. The exteriority of illeity, refractory to disclosure and manifestation, is a having-to-be in the face of another. In it there is announced not a Sollen, which is always asymptotic, but glory ${ }^{25}$.

I do not know the name of the woman in Chicago, I do not know where she was from or how her voice sounded like. In many ways, everything that I said about her situation was spoken from my point of view. From where I stood I could not really know whether or not she was really hungry, if she was really poor or if she had lead a violent and unfulfilled live. And yet, had I introduced myself to her would it then be the case that we would enter an ethical relation?

On his masterpiece, Otherwise than Being, Levinas describes the paradoxes that are at play in these relations of recognition and of doing Justice to the Other in terms of transforming the intimacy of being-inlanguage into an ethical relation of dialogue. An important point here is that if intimacy is always haunted by the ghost of totalization, of attempting to reduce the emergence of something other than the self to the same: ethical language still remains spoken. The paradox is precisely that the possibility of an ethical language is at conflict with the fact of Being in language. The description that "beyond being turn into ethical language" is still a description of sorts, it is still linguistic.

But allow me to keep the issue of ethical language within the terms that Agamben brought: what if ethical language is a different mode of situation of Being? What if it is a dislocation of subjectivity to an outside of the tension between private and public life and into an ethos. In this sense, it is as if Levinas proposes a third mode of being to the classical

${ }^{25}$ Levinas, Otherwise than Being [Henceforth OB], p. 193 
division of bios and zoe: an ethical form of live which is experienced in a way that cannot be represented but can paradoxically be lived.

Agamben seems to have been able to understand that the hunger that one expresses is not only a need to eat, the woman in Chicago might be even overstating her starvation, she might not even feel a physiological hunger. However, it would be difficult to deny that a beggar has a political hunger and obliges us to ask the question "why is it him and not me?". Agamben has suggested that the separation of physiological and political no longer makes any sense here, and Levinas seems to have pointed at a similar direction but with a different intent.

If Agamben points at the issue from a highly anti-humanistic and anarchistic point of view, Levinas seems to attempt to re-situate the issues of responsibility for the other in the structure of an ethical response. In Levinas, the bare woman in downtown Chicago is the embodiment of the Ethical, she operates as a third, as an absolute stranger. The woman interrupts my relation to my familiar surroundings, to my neighborhood, and situates myself in a different place altogether. This place is the ethical ground wherein I can now be conscious of a possibility of Justice. In a sense, the shame that arises from the encounter with the third person also gives rise to the possibility of Justice.

But Levinas would be quite suspicious of Agamben's option towards an eudaimonia rather than an Ethics of Responsibility. For Levinas, the ethical is never said or lived it is a situation wherein one is put in necessary relation to something other than oneself. In a way, speaking of ethics in Levinas seems to be impossible - and it is especially absurd, it seems to me, to suggest that anyone is Ethical in any way. After all, the ethical seems to be a form of worldliness where one is bound to respond to an Other.

IV

There is a crack in everything That's how the light gets in ${ }^{26}$.

When Virgil finds Branca Doria in hell his first reaction is of surprise: how can Branca Doria be in hell if he eats, drinks and wears his clothes in Genova? After a while it becomes clear that Branca's body is in

${ }^{26}$ Leonard Cohen, Anthem. 
Genova, but his soul already breathes in Hell. His existence had already drowned into oblivion.

The period in literature is rich in these sorts of paradoxes which try to make sense of our own position as both active subjects that seek to understand something about our surroundings while at the same time being affected by phenomena we cannot quite reduce to words. The unspeakable horror of the situation in the camps and the beauty of a loved person are always in tension with ourselves.

In the start of this essay I described the subject as broken, as always exposed to its own pathos. In Levinas, this experience of nausea or malaise is shame. In Agamben, this is the bare life of an individual that discovers in its nudity - its own potential to become itself and live one's own life.

From a philosophical standpoint, however, there is plenty to be said about the problems in both analysis. If Levinas is successful in describing the limitations of the self and the need to account for the Other within a different discursive framework, it is still not clear what is it that we can really do about it. This is perhaps a critic that goes outside the scope of the Levinasian analysis, but it seems to me that if his concern is with the field of Ethical Theory and the modes in which we can account for the other in philosophy, it is not enough to describe how our forms of description or relation with the other ought to be. It is, of course, an interesting exercise in philosophical abstraction, but if we want to insist on the concreteness of the situation of the poor, the widow and the refugee, we also need to focus on the need of developing policies in order to deal with these situations. Levinas does not propose any policy. He rather suggests that thinking policies through might even indicate an attempt of totalization but I am not sure that any policy would fall into this problem. At least not for Levinas - and perhaps that's the bridge that needs to be thought: one that takes the Levinasian take onto political philosophy (or at least a kind of policy towards those who need government).

However, if Agamben is proposing a sort of Levinasian take on political philosophy, I am increasingly convinced that it is not a profitable one. In Homo Sacer, I, II and III, along with "in this exile" and several other essays, Agamben takes a number of false premises as the justification for his arguments. For example, the question of the placement of the poor and the failure of modernity is taken according to an assumption that poverty, 
violence and sickness have been increasing ${ }^{27}$. There is no way one can take this argument to be the case. All statistics indicate that the world is less poor, less violent and less sick than it was 70 years ago. Even with two world wars and two major economic collapses, the twentieth century marks an improvement in the global condition of life. Plenty of people way more than it is tolerable, for that matter - live behind the poverty line, but we will not understand their condition by assuming that the global situation has been getting worse.

If we are to understand the ambivalences and problems of contemporary politics - and the surprising absence of a liberal philosophy that takes the body seriously is an important issue to be taken here - we also need to admit some of the achievements of modern and liberal philosophy.

The recent problems with abuse of executive power in developed democracies - and the cases of torture in the United States are just one example - are a recent reminder of the fragility of the institutional framework that we trust to govern ourselves. However, we have no reason to believe that without the protection of this institutional framework we would be in a better position. Agamben seems to think so, but, as I have pointed out, his premises are wrong. Now, Levinas may indeed have suggested some important points we need to focus on, that is, that even as we experience an increase in the comfort of our own private lives, our surroundings might be artificially constructed so we do not really need to face those who are in a position of fragility. It is problematic that we once again see the nation-states excluding the life that is not worth of protection. In reality, this process has never really stopped. But increasing the scope of protection of human rights and justice is also a project of modernity and Levinas has much in common with Kant in his attempt to say that every human life, in its fragility, is worth of being protected and recognized. Still, unlike Kant - and here the bridge with a political philosophy is yet to be built -, Levinas is suggesting that we should move away from a normative-reflexive conception of a person and focus on the materiality and concreteness of the ethical relation in order to be able to really make justice to the Other.

${ }^{27}$ IE:128; 133 
F. Pontin - Shame, de-subjectivation and passivity - on the metaphysics of the Self in | 205

\section{Bibliography}

AGAMBEN, Giorgio. Remnants of Auschwitz: The witness and the archive. New York: Zone Books, 2002.

. Means without end : Notes on Politics. Minneapolis: University of Minnesota Press. 2000

LEVINAS, Emmanuel. Totality and Infinity. Pittsburgh: Duquesne University Press, 2007 On escape. Stanford: Stanford University press, 2003

.Otherwise than being. Pittsburgh: Duquesne University Press, 1998

STEINBOCK, Anthony. "Generativity and the scope of generative phenomenology" in WELTON, Donn. (Org) The New Husserl: A critical reader. Bloomington: Indiana University Press, 2003

Endereço postal:

Programa de pós-graduação em filosofia da PUCRS

Av. Ipiranga 6681, Prédio 8, 4 andar, Porto Alegre, RS - Brasil

Data de recebimento: 07/03/2018

Data de aceite: 12/03/2018 